\title{
Исходный материал мягкой яровой пшеницы \\ на устойчивость к полеганию и продуктивность
}

Айтбаева Р.Н.*, Новохатин В.В.

Тюменский научный иентр СО РАН, Тюмень, Россия

*e-mail:natalya_sharapov@bk.ru

Повышение урожайности неразрывно связано с устойчивостью к полеганию, которое обусловлено анатомо-морфологическими признаками стебля. При этом длина стебля отрицательно коррелирует с устойчивостью кполеганию $-\mathrm{r}=-0.570 \ldots$ -0.670 (при $\mathrm{R} \geq 0.273$ ), что характерно и длине второго нижнего междоузлия $\mathrm{r}=-0.528 \ldots-0.781$. В то же время устойчивость к полеганию в большой степени зависит от диаметра второго нижнего, опорного междоузлия, что подтверждается положительной сопряженностью $-\mathrm{r}=0.476 \ldots 0.586$. Положительно выраженные различной степенью сопряженности анатомических признаков: число и диаметр СВП, толщины склеренхимного кольца и стенок междоузлий с основными элементами морфологии стебля позволяют использовать последние в качестве маркерных признаков при оценке сортов на устойчивость к полеганию. При этом следует учитывать, что длина стебля до значительной степени $(\mathrm{r}=0.655 \ldots 0.756)$ оказывает влияние на продуктивность, а полегание отрицательно $(\mathrm{r}=-0.305 \ldots$ -0.438) коррелирует с качеством зерна: белок, клейковина, ИДК. Низкостебельные сорта, несмотря на хорошо выраженные анатомо-морфологические признаки стебля, слабо адаптированы к местным условиям, поэтому используются в селекционной работе как промежуточные формы. В то же время среднерослые, устойчивые к полеганию генотипы Скандинавских стран и Северной Европы довольно хорошо адаптированы к местным агроклиматическим условиям, где показывают хорошую продуктивность и широко используются в селекционной работе. Из изученных 126 сортообразцов коллекции ВИР - 12 устойчивые к полеганию, с высотой растений 76-93 см, при высоте стандарта Тюменская 29 86-95 см и полегании 3-4 балла. Среди них шесть сортообразцов: Aletch (к-65011), Remus (к-66025), Trappe (к-66027), Lona (к-66030), Greina (к-66031), Toronit (к-66032) и Molera (к-66033), в благоприятных условиях выделились довольно высокой средней урожайностью - от 497 до 567 г/м² при осредненном стандарте Тюменская 29 - 447 г/м². Сортообразцы: Aletch (к-65011), Toronit (к-66032), India 288 (к-65116), Мажор (к-65271), Гренада и АВИАДа устойчивы к предуборочному прорастанию зерна в колосе. Повышенная белковость (17.317.7-18.0 \%) наблюдалась у Бисерти, Жигулевской, Тюменской 29 и Боевчанки. Высокой продуктивностью выделяются Jin Mai 71 (к-65813) (559 г/м²), Арка (561), Гренада (592) и Алабуга (633 г/м²). Выделенные сортообразцы рекомендуются для системных скрещиваний, ступенчатой гибридизации и беккроссной селекции. 